\title{
Masak, Macak, Manak Nowadays through Challenge-Based Research on Nol Dance Creation
}

\author{
Yulela Nur Imama a,1,* Michiyo Yoneno Reyes ${ }^{\mathrm{b}, 2}$ \\ ${ }^{\text {a }}$ Pascasarjana Institut Seni Indonesia Surakarta, Indonesia \\ ${ }^{\mathrm{b}}$ Institute for Advanced Studies on Asia (IASA), University of Tokyo, Japan \\ 1 yulelanurimama@yahoo.com*² michiyoy@yahoo.com \\ * Corresponding Author
}

Received 2020-09-04;

accepted 2021-02-27;

published 2021-10-19

\begin{abstract}
AB STRACT
Patriarchy in Javanese culture gives birth to gender stratification between women and men. This attitude has an impact on the work delegated to women. This stigma requires women to fulfil cultural values that include $3 \mathrm{M}$, namely masak, macak, manak. This study aims to find out the existence and relevance of the values of masak, macak, and manak, in the form of dance works, and to find out how these values must be maintained. The method used is the method of creation based on the concept of art-based research. This research on the creation of dance works is based on challenges, namely through the process of creating challenges. The study was conducted by challenging ten participants to communicate and do several things intensely, both personally and communally, for seven days online through the "7 days cooking" challenge. The results of this study are in the form of dance performances containing messages of masak, macak, and manak which are displayed live streaming on the Youtube social media channel.
\end{abstract}

KEYWORDS

\author{
Masak, macak, \\ manak; \\ Existence of cultural \\ values; \\ Challenge-based \\ research
}

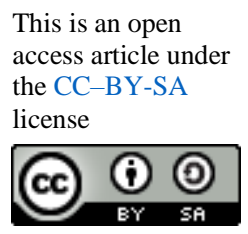

\section{Introduction}

The value of Masak, macak, manak is a cultural value that is identified in Javanese women (Riany, Meredith, and Cuskelly 2017; Fitrianggraeni 2019). This value refers to a patriarchal culture that is passed down from generation to generation (Goa, Rachmawati, and Ungsianik 2021; Little and Winch 2017). Macak means a woman must make up, dress up and dress well to look beautiful. This is done in order to serve the husband. Manak is meant as conceiving, giving birth, breastfeeding, to the stage of educating and caring for children. Meanwhile, masak means taking care of kitchen matters. Masak in this case not only provides food and drinks, but also manages the monthly budget properly. This is a form of devotion for a Javanese woman to her husband. A Javanese woman must be good at masak, macak, manak (Mawaddah, Suyitno, and Suhita 2021; Retnaningsih 2013). If these three things fail to be carried out, he is considered of no value both in the family and in society and becomes a family disgrace (Widayati et al. 2018). Over time the value of masak, macak, manak experiences a shift in meaning. Emancipation and globalization have steadily shifted the status of married women in Java, transforming them into garwo - sigaraning nyowo (half of the husband's life), who play an equal and essential part in realizing the concept of dadi wong in society (Muhmad Pirus and Nurahmawati 2020). From a traditional idiom agreed upon by the Javanese people, it becomes a wind that blows in the subjectivity of each community's instincts. Like foklor but still exist, it is applied non-verbally and conspicuously. The existence of these values is very interesting because of the diversity of appreciation, interpretation and application in society, especially Javanese women today.

Along with the development of the era and the level of intellectuality in which there has been a social change in society, it has given rise to several new patterns of thinking about cultural values (Rioufol 2004). Many research results show that patriarchal ideology is increasingly giving space for the existence of women as an important subject (Greene and Kahn 2020; Bannerji 2020). This is the momentum that becomes the entry point for the idea of creating works. The creation of Nol dance works through strategies and creative processes aims to find the existence and relevance of the values of masak, macak, and manak today, how these values should be maintained or not and how to see, respond to, and treat these values if they are associated with an achievement of quality of life today. This process is useful for reflecting on cultural values, especially masak, macak, and manak which 
are not intensely aware of and building this awareness in each person for the present and the future with rich and appropriate interpretations. As a way to achieve the expected goals, Nol dance uses a strategy of creating works that are discovered and applied by the authors, namely "challenge based research" (Chen and Eisenberg 2020). Through this strategy, the authors challenged ten participants to undertake several challenges related to the research achievements of Nol dance creation.

\section{Method}

Nol dance uses the terminology of creation based on the concept of art based research (Bakirova et al. 2021). Where the author conducts art research using perspective and involves developing sensitivity in art all the time in an effort to generate and present data. This is supported by conducting research on the public space on the cultural values of masak, macak, manak. Terminology of art based research, art work is made through a process that reflects the process of investigation in other fields; ends in a product affixing the process through which the information is generated, analyzed, and interpreted (McNiff 2011). To support the art-based research, the author takes several steps as a strategy for his creation. The first step, the authors conduct research ethically with an emphasis on the cultural philosophy of masak, macak, manak in Javanese society until its development and a contextual view of these values. The next stage is emic research by directly plunging into the public space to conduct a research which gives birth to a neutral interpretation regarding the cultural values of masak, macak, manak. The next stage, the writer takes an approach to the culture space that will be specifically processed, the approach taken is an approach to the social environment, the cultural environment, and the spatial environment. Next, the final exploration and formation is carried out. Nol dance is born as an embryo that continues to develop through ongoing experimental work connecting the public as its neutral object. This work Nol dance has been carried out through five stages of work until now.

\section{Results and Discussion}

\subsection{Visualization of Masak, Macak, Manak Value in Nol Dance}

Nol dance adopts the cultural values of masak, macak, manak which have a wealth of value interpretations. Nol is associated with a number that refers to a void or the beginning of before the "being". Nol also refers to a circular, round, round shape which the worker correlates with the symbol of womanhood. Nol is interpreted by a woman who becomes the media to transfer the new human life from nothing to being. Nol is also synonymous with the mortar/ cobek/ ulegan shape used as a form of interpretation in this work. In the shape of the round mortar, the processing of spices, the process of working, the process of mixing, adding and subtracting is born, giving birth to a new taste. The object of the mortar is closely associated with the value of masak, macak, manak carried in the work of Nol. This is because the masak value contained in the mortar is an object used to process the spices to be cooked or an object used to process food making. Furthermore, the correlation of the value of macak is adopted from the term taken from the uthor's father perspection, namely that a woman will radiate an aura of beauty when using a mortar. Finally, it is associated with the value of the manak that gave birth. Primamona explained that Alu and lesung are symbolized like lingga (male sex) and yoni (female sex) who work together to carry out their duties in processing to produce something new, the results of refined spices are likened to children or the new work they produce. The meeting of the two (linga and yoni) is a very clear picture of the sexual relationship between men and women, which is interpreted as a symbol of fertility (Gottowik 2019). After going through a long work journey, the values conveyed in Nol works have become so rich, coupled with the limitations of pandemic conditions and situations, which have created gaps and new strategies and resulted in flexible and rich values (Coyne et al. 2021). The value of masak, macak, manak is not only related to gender and its existence today as cultural values only. This value is considered to be a vital value if it is associated with achieving the quality of life during a pandemic. Just like masak is not only associated with the activity of women to process food to be served in their family, but an activity that is needed by every human being to survive without depending on other humans. Macak is associated with a product that is created by yourself for yourself in any form, not just physical but can include brain, beauty, behavior. Furthermore, manak is related to how we can make achievements or give birth to a value for ourselves in this limited time. There are still many interpretations of the value of masak, macak, manak which are considered to be stereotyping for certain people, which are very relevant to the 
present and can be applied in any form and in any intensity. So, the value of masak, macak, manak is not just for women in Javanese society, but for all people who are aware of and need it.

\subsection{Research as an Art Process}

Nol's dance work goes through a long journey with research both epic and emic. The research involved several personalities with different backgrounds in several public spaces such as traditional markets, cafes, parks, car free days. In Figure 1 is the research process of Mrs. Sutarni at Pasar Gede Surakarta.

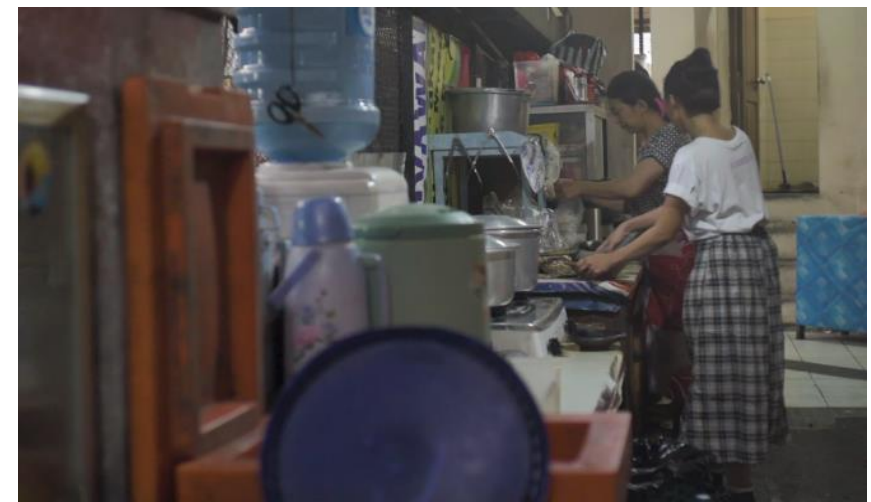

Fig. 1. The research process of Mrs. Sutarni in Pasar Gede Surakarta (Source: Ardho Kalis. 2020)

The form of this research is to conduct interviews related to the cultural values of masak, macak, manak according to the perspective of each person. During the interview, the process of nguleg or mashing the spices according to each personal version was also carried out and told about it. First, the authors conducted interviews in Pasar Gede by obtaining several samples and backgrounds. Both interviews were conducted at Gendon Humardani Park at ISI Surakarta, and the last research interview was conducted at Slamet Riyadi Car Free Day (CFD) Surakarta. Interviews conducted at Car Free Day (CFD) Slamet Riyadi Surakarta, shown in Figure 2.

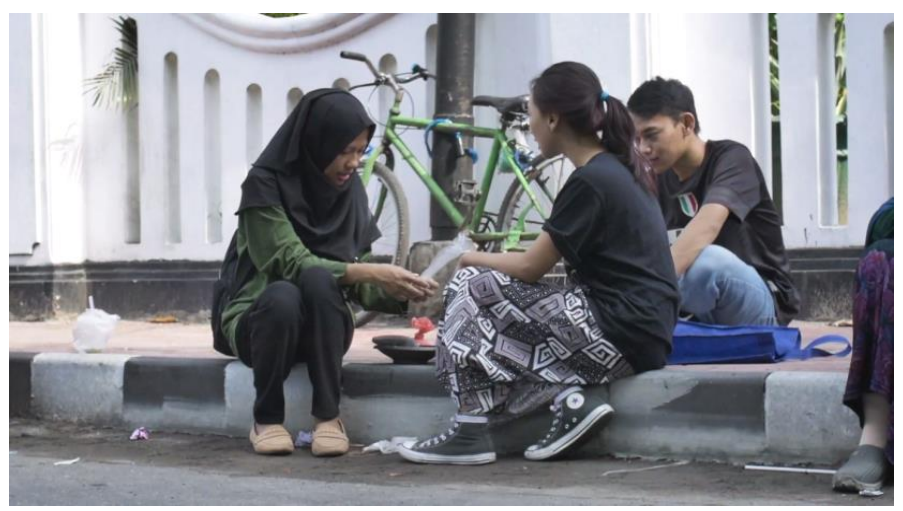

Fig. 2. The research process of Riska at Slamet Riyadi CFD Surakarta (Source: Ardho Kalis. 2020)

The results of this research, the authors found some data on the response of the nguleg to the body with different backgrounds. There is a boy who gets cultural values from a grandmother and produces very subtle spices, there is also a career woman who has never been subject to cultural values and produces harsh spices.

\subsection{Work in Progress Based on Experimental Performances}

Nol dance works is a work that grows. Therefore, this work is a work that has gone through several work processes, from research to work in progress. From the research that had been done previously on Nol works, several work in progress was carried out as well as a research medium for further works. The work in progress continuously finds new discoveries on the cultural values that develop in society. The first work in progress was carried out in Rumah Barata Art Space. Appreciators witnessed firsthand how the research process was carried out by interviewing resource persons and relating them 
to the issue of manak from the perspective of Javanese women today. In Figure 3, is the process of work being compiled by Yulela Nur Imama.

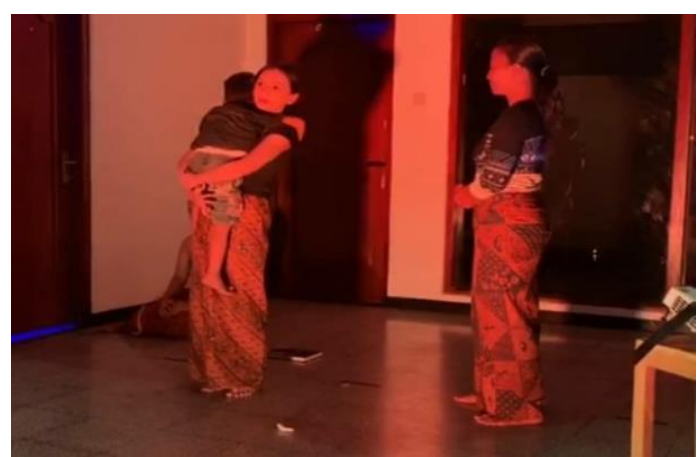

Fig. 3. Work in Progress by Yulela Nur Imama (Source: Yusak Risal. 2019)

Work in progress was then performed at the Gendon Humardani park of ISI Surakarta, through a ulegan response to the body by presenting the results of research through video as an appreciative interpretation medium, as can be seen in Figure 4.

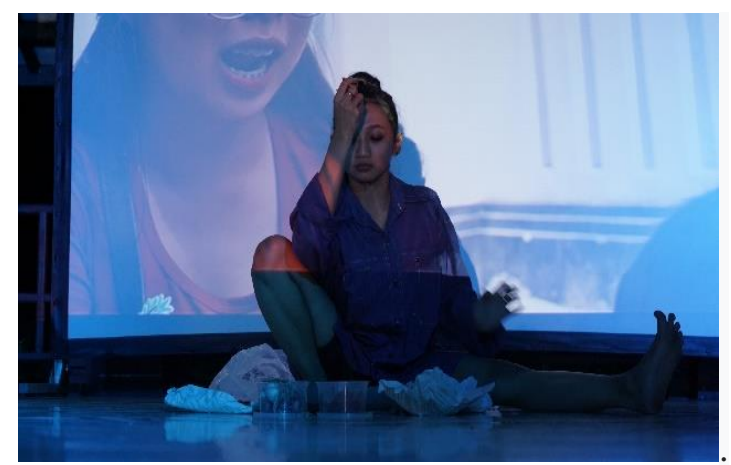

Fig. 4. Yulela's Work in Progress (Source: Yusak Risal. 2019)

The next work in progress was carried out at Feodal Art Space. In this work in progress, it emphasizes the experimental social environment of the show in spontaneous nguleg activities with the audience. This nguleg activity can be seen in Figure 5.

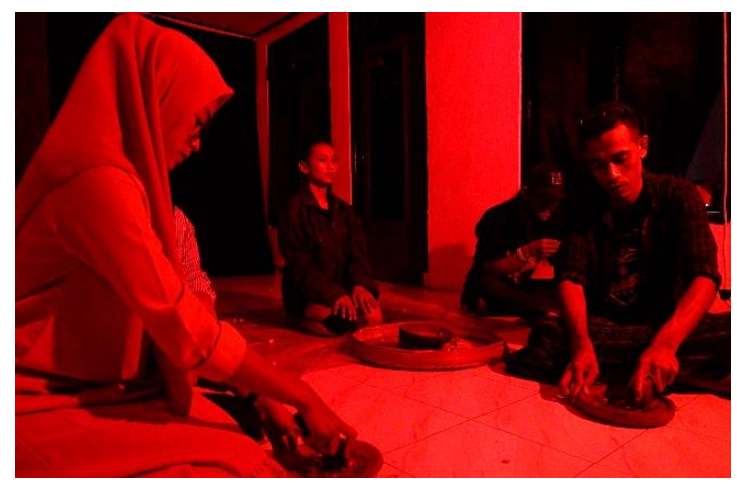

Fig. 5. Work in Progress by Yulela (Source: Mega Yunita. 2019)

\subsection{Challenge based Research}

As a further form of research in Karya Nol as well as to create an alternative in the creation strategy during a pandemic period, a new strategy was created which was possible to be implemented indirectly. The strategy is challenge based research, which is challenge-based research that enables a creation study of participants to interact and perform the artistic process indirectly. The strategy is carried out online or utilizing social media channels as a medium for the art creation process. This strategy was created by creating a platform that invites participants who are interested in the issue of 
the existence of cultural values of masak, macak, manak, to then carry out a challenge and online discussion together. In Figure 6 is a model of challenges and online discussions provided in the form of a platform whose contents are respondents' responses to the 7 Day Cooking Challenge.

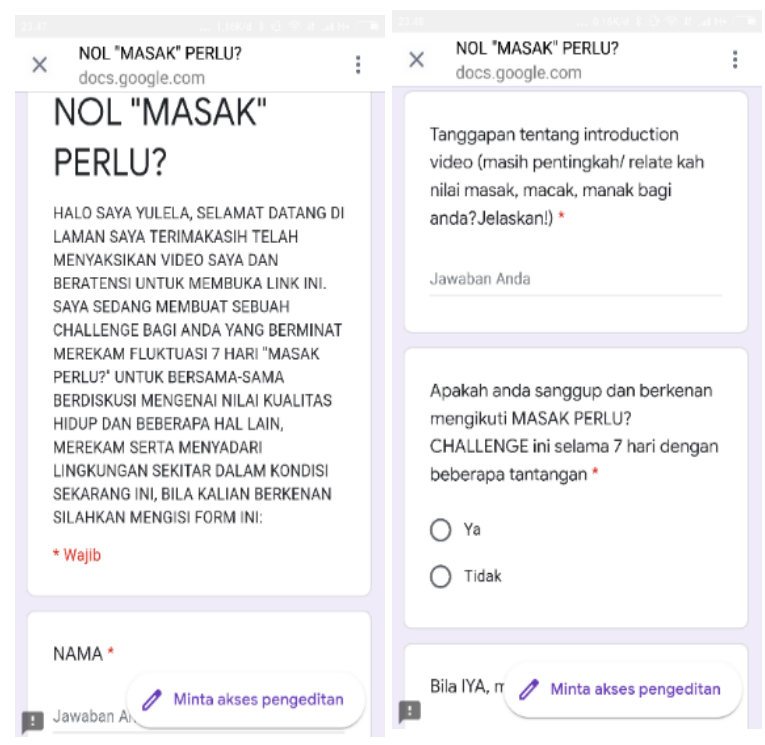

Fig. 6. Platform for filling out respondents' responses to 7 Cooking Days Challenge

The stages in the research process are divided into several stages; First, make an introduction video containing an issue raised by the author in his challenge based research. In the video, the author invites all groups regardless of gender, background, and age to join together to take part in the challenge called "challenge 7 days Masak Perlu?". The challenge refers to a question of reflection about whether we still need the value of masak, macak, manak, in this time, as well as having an interpretation whether the ability to masak or process a food is still needed today. The video introduction directs anyone who wants to respond and provide feedback to fill in the form provided in the author's Instagram bio. Post in the Introduction videos on Instagram and Youtube, can be see on Figure 7.

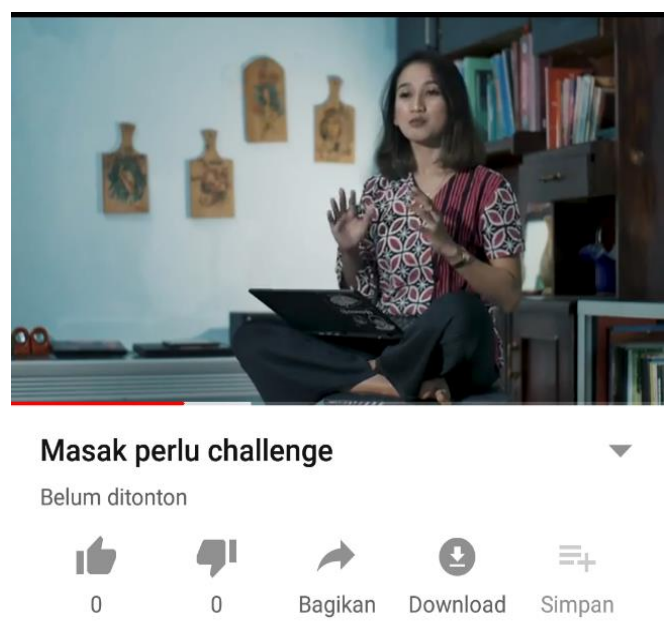

Fig. 7. Post in the Introduction videos on Instagram and Youtube

The second stage in this research process is, after making introduction videos that are posted on Instagram and YouTube and shared online, the authors select respondents who want and are interested in the issues raised and are willing to take part in the 7 day challenge Masak Perlu? After selecting based on answers and several considerations, the employee contacted the potential participants one by one by sharing technical instructions and a two-way agreement made by the working team. As for the challenge-based research process in the "7 Days Masak Perlu" challenge. these include; 
- Day 1 (11th June 2020) - Challenge of Siapa Aku? On this first day, participants started with an introduction of themselves, the introduction included name, age, occupation, regional origin, daily activities, telling about how they view the cultural values of masak, macak, manak today, and several things discussed. both ways related to identity and background. On the first day of this challenge, the authors tried to dig up personal backgrounds related to their respective cultural values which were linked to a personal view of themselves. The author asks participants to write five sentences that represent a description of themselves related to cultural values. Then the writing is placed in the place that participants see and read most often (on the desk, on the bed, etc.). The challenge on the first day emphasized more on each person as a reflection of his own perception of himself and questioned whether those assumptions were really a description of him. After doing the challenge on the first day, the authors found a very rich interpretation of the cultural values of masak, macak, manak. Many views emerged from each participant regarding a cultural value that is self-respecting (Figure 8).

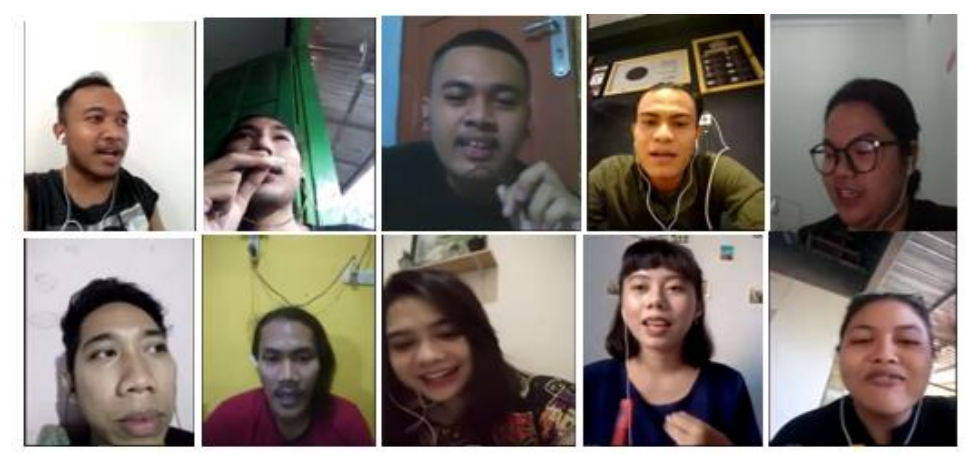

Fig. 8. VC Challenge Day 1, Cook?

- Day 2 (12 June 2020) - Mari Bercerita; On the second day of this challenge, video calls were held collectively, namely bringing together ten participants in a discussion forum room regarding self-opinion and efforts to achieve quality of life associated with the values of masak, macak, manak. On this second day the participants read out their respective descriptions of "siapa aku" that had been written in the previous challenge. Lots of new things to be obtained and shared in the forum on the second day. Especially regarding a cultural value perspective of masak, macak, manak which is associated with efforts to achieve quality of life. Especially in this time of limitation, with their respective worries, participants can provide fresh air for others regarding alternatives in survival.

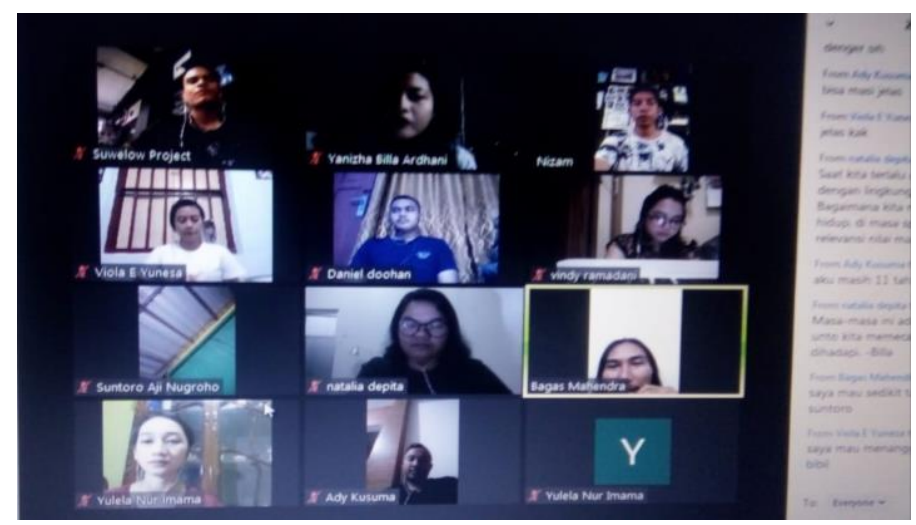

Fig. 9. VC Challenge Day 2

- Day 3 (13th June 2020) - Melihat Sekitar; The challenge on the third day was to record the environment around each participant that they found interesting for three minutes. On the 3rd day we discussed our awareness of the values we already have towards the environment at this time (pandemic). On this third day of challenge, it gave birth to a new reflection about the slightest concern of the personal to the surrounding environment that may not have been thought of at all. Because, with this pandemic, each person is busy with confession (how to 
survive, how to live, how to stay safe) and so on. In this challenge, the authors tried to invite participants to tap and bring up just a little of what was happening around us. Because, paying attention to an object for three minutes will make participants think there is another life that is happening in harmony in their present life.

- Day 4 (14 June 2020) - Masak Iya? On the 4th day, the authors challenged the participants to make a spice that is mashed with a mortar / ulegan (it is up to the spices or the composition) which according to the participants is the best composition and composition (for example, using bay leaves and ginger in cooking. soup to produce a certain quality). Then the participants told when they made a video call about the technique of making spices, the dose of spices, the taste to be obtained, and the name of the spice as an interesting new discovery in the participant's life. This challenge on the fourth day gave birth to a value of appreciation for any small process in any form. By analogizing the process of processing spices that goes into a private space, people usually don't see the processing process but the result (except for the chef), with this online nguleg challenge, participants are appreciated for showing each process in any form. See Figure 10.

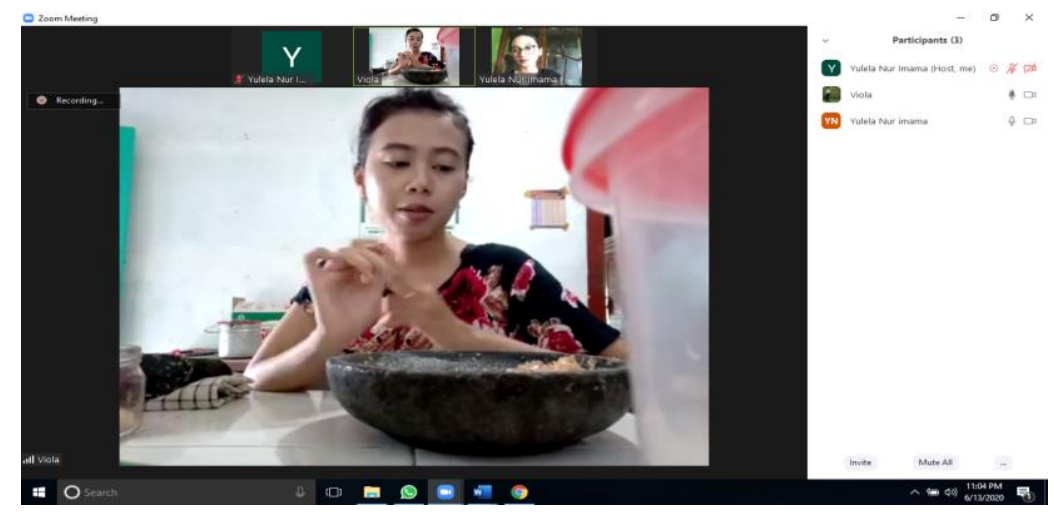

Fig. 10. VC Challenge Day 4, Masak Iya?

- Day 5 (15th June 2020) - Macak; On the 5th day, the participants were given the task to prepare the five most favorite clothes according to their respective versions. Then, when VC, participants introduced one by one their clothes the reason they liked these clothes see Figure 11. Then the participants were asked to mix the five clothes into three styles according to their version. Of the clothes worn, participants are required to state the reasons why they wear this style, then what they feel when wearing it, where the clothes are usually used. Then the latter questioned again what is the value of macak for each person.

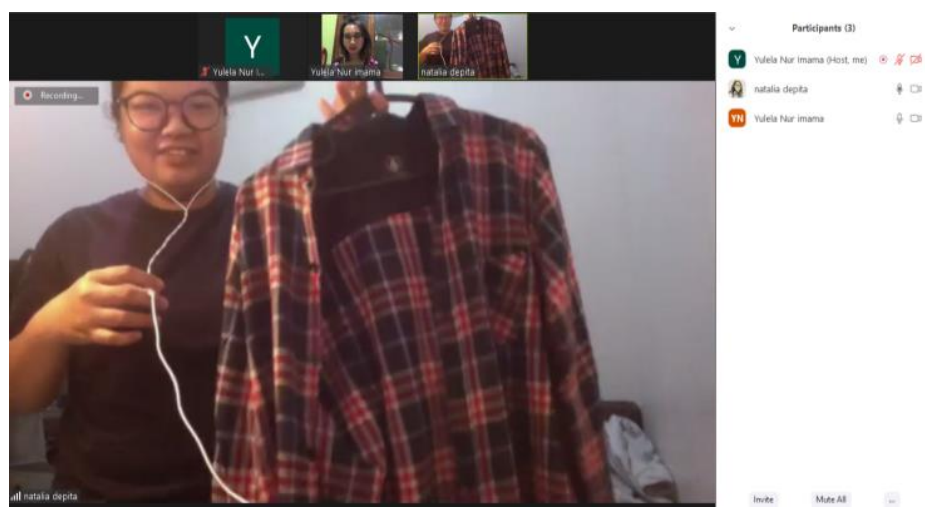

Fig. 11. VC challenge day 5, Macak

After the challenge takes place there is a value that can be drawn that the value from the outside is meaningless until the self respects his own judgment in any form. The interpretation of the value of macak becomes very rich and does not lead to a literal meaning when faced with various persons with different backgrounds. Some of the personalities consider the meaning of 
macak as a stigma in oneself, giving an identity in any form, and a journey to improve according to their respective versions.

- Day 6 (16 June 2020) - Cobek Adalah; In this sixth challenge, see Figure 12, the author invites the participants to communicate through ulegan media. By answering every question the author gave through clapping, rubbing, and body gestures to each participant, which represented the expression of their hearts. These questions include; (1) what is the manak value for you?; (2) what manak value applications have you lived through so far?; (3) have you always wondered how a long process in life ends?; (4) with whom do you want to live in the moment?;(5) As a human being, is sexual activity at this time a natural activity for you?(6) If the meaning of manak is as small as containing and giving birth, which makes you think that the value of manak is an important value besides continuing the generation yourself?; (7) What are you going to do and want to do in the next five years or so regarding the value of manak?; (8) What makes you feel the most meaningful as a human being?(9) Tell me something that you always keep tidy, and you don't want to tell anyone, but today you want to tell me! The sixth day of the challenge relates to something that is conveyed using a feeling that will also be accepted by taste. On the sixth day, the authors tried to get all the participants to be honest about what they felt, especially regarding the value of manak which is literally difficult to explain to just anyone.

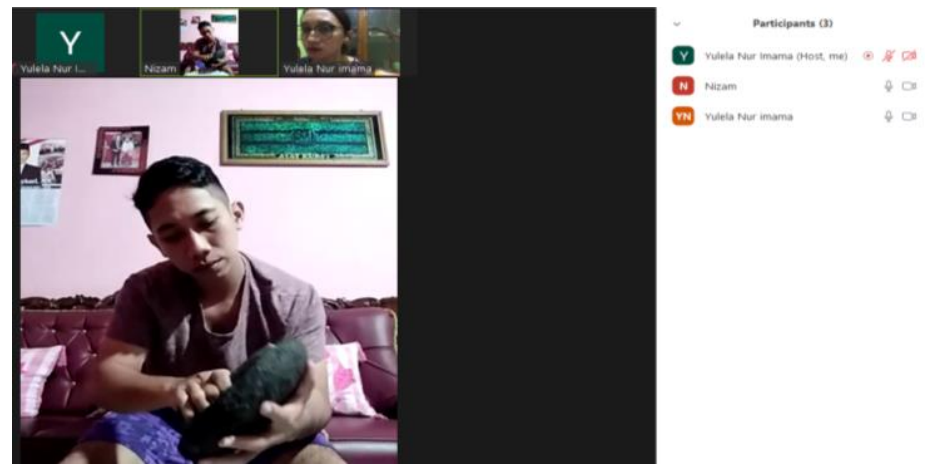

Fig. 12. VC challenge day 6 , Cobek adalah

- Day 7 (17th June 2020) - Masak Perlu?; see on Figure 13. On the seventh day of the challenge, each participant collected a video recording of efforts to achieve the quality of life version of each participant during the pandemic. Then we made a video call collectively and played each other's videos through the share screen video call zoom. After that on the seventh day we appreciated each other about the achievements of each participant in any form. In this challenge, an explanation is given about the achievements made in the 7 day Masak Perlu challenge. In this challenge, it focuses on cultural values that affect each person that is learned through several discussions and the ways a person carries out activities, especially in limited times in this pandemic era.

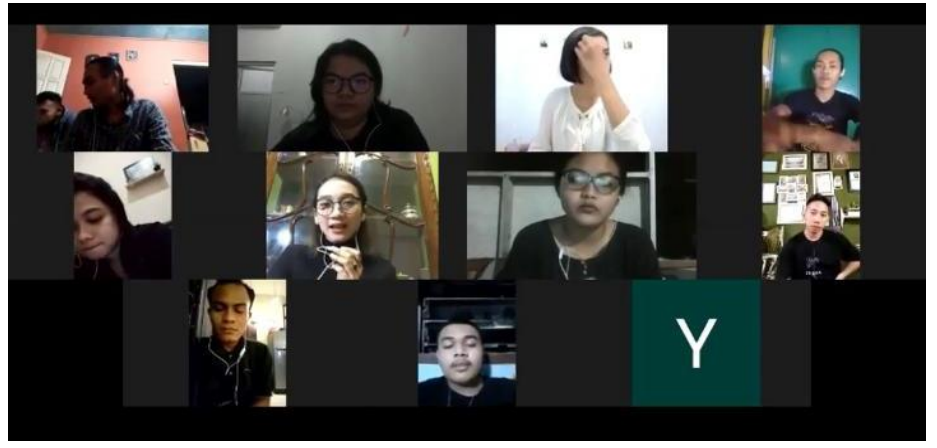

Fig. 13. Video call for the 7th day of the Masak Perlu challenge

The last day of 7 days Masak Perlu challenge generating a perception about the smallest achievement is an achievement that must be appreciated, which must be conveyed through positive energy, and the perception of value is only a value. The most important thing is how to interpret a 
value. In human age it is very limited to do whatever this is, the only thing that can be counted on is oneself with the values in it. Masak, macak, manak are not as small as the definition, but more than that, masak, macak, manak is an effort to achieve a very meaningful quality of life. Not only for women, especially Javanese women. Masak, macak, manak is a value for living humans who are able and willing to do and realize it.

\section{Conclusion}

The creation of Nol's dance works is a strategy and creative process that has succeeded in finding its relevance in the midst of society affected by the pandemic. The current values of masak, macak, and manak can be related to the achievement of the current quality of life. This work is useful for reflecting on the values of patriarchal culture, as well as providing benefits for others in building selfawareness, that everyone has their own role without negating the others.

\section{References}

Bakirova, Samal A., Toigan O. Izim, Lyudmila A. Nikolayeva, and Gulnara Yu. Saitova. 2021. "Choreographic Art Features: Creative Concepts and Innovations in Teaching." Thinking Skills and Creativity 41 (September): 100901. https://doi.org/10.1016/j.tsc.2021.100901.

Bannerji, Himani. 2020. "But Who Speaks for Us? Experience and Agency in Conventional Feminist Paradigms." In The Ideological Condition: Selected Essays on History, Race and Gender, 53-80. Brill.

Chen, Tony, and Michael L. Eisenberg. 2020. "Challenges in Survey-Based Research.” The Journal of Sexual Medicine 17 (11): 2115-17. https://doi.org/10.1016/j.jsxm.2020.08.013.

Coyne, Lisa W, Evelyn R Gould, Mikala Grimaldi, Kelly G Wilson, Gabriel Baffuto, and Anthony Biglan. 2021. "First Things First: Parent Psychological Flexibility and Self-Compassion during COVID-19." Behavior Analysis in Practice 14 (4): 1092-98.

Fitrianggraeni, Setyawati. 2019. "Building Business, Enriching Lives: An Indonesian Initiative to Empower Women in the Fishing Communities." WMU Journal of Maritime Affairs 18 (4): 595-616.

Goa, Maria Yasintha, Imami Nur Rachmawati, and Titin Ungsianik. 2021. "Paternal Self-Efficacy in the Patriarchal Culture of Kupang City, Indonesia." Enfermería Clínica 31 (April): S457-60. https://doi.org/10.1016/j.enfcli.2020.09.045.

Gottowik, Volker. 2019. "Playing With Images: The Visualization of the Other in Hindu-Balinese Religion." International Journal of Interreligious and Intercultural Studies 2 (1): 78-91.

Greene, Gayle, and Coppelia Kahn. 2020. "Feminist Scholarship and the Social Construction of Woman." In Making a Difference:, 1-36. Routledge.

Little, Ben, and Alison Winch. 2017. "Generation: The Politics of Patriarchy and Social Change." Soundings 66 (66): $129-44$.

Mawaddah, Haalin, Suyitno Suyitno, and Raheni Suhita. 2021. “Javanese Women's Efforts to Face Patriarchal Culture in the Novel Para Priyayi by Umar Kayam." International Journal of Multicultural and Multireligious Understanding 8 (1): 100-110.

McNiff, Shaun. 2011. "Artistic Expressions as Primary Modes of Inquiry." British Journal of Guidance \& Counselling 39 (5): 385-96.

Muhmad Pirus, Mohd Shahnawi, and Hany Nurahmawati. 2020. "Javanese Women Identity Regarding 3M: Macak-Manak-Masak Values." International Journal of Culture and History 7 (2): 54. https://doi.org/10.5296/ijch.v7i2.18055.

Retnaningsih, Umi Oktyari. 2013. "Indonesian Educated Unmarried Career Women: Gender Inequality, Discrimination, and Prejudices." Asian Women 29 (1): 5-25.

Riany, Yulina Eva, Pamela Meredith, and Monica Cuskelly. 2017. "Understanding the Influence of Traditional Cultural Values on Indonesian Parenting." Marriage \& Family Review 53 (3): 207-26. https://doi.org/10.1080/01494929.2016.1157561. 
Rioufol, Véronique. 2004. "Approaches to Social Change in Social Forums: Snapshots of Recompositions in Progress.” International Social Science Journal 56 (182): 551-63.

Widayati, Mukti, Farida Nugrahani, Titik Sudiatmi, Benedictus Sudiyana, and Joko Suryono. 2018. "Representation Women Subordinated of Java Culture in Bumi Manusia by Pramudya Ananta Toer." In 2nd Workshop on Language, Literature and Society for Education. European Alliance for Innovation (EAI). 